УДК: 373.24:376.2

DOI: 10.26697/ijes.2019.4.17

\section{Готовність дошкільних закладів освіти до роботи 3 дітьми 3 інвалідністю}

\author{
Полівко Л. Ю. ${ }^{1}$ \\ ${ }^{1}$ Київський начіональний університет імені Тараса \\ Шевченка, Україна
}

\begin{abstract}
Резюме
Вступ:

Проблема навчання та розвиток дітей 3 інвалідністю $\epsilon$ досить розповсюдженою та актуальною темою у нашому суспільстві. Кількість навчальних закладів, де сміло набирають таких дітей, збільшується 3 кожним роком. В першу чергу, це спричинено і запровадженим законом про інклюзію, де всі діти з інвалідністю мають право навчатися у звичайних школах. Проте, слід зазначити, що не всі навчальні заклади мають належну підготовку щодо роботи 3 дітьми такої вразливої групи, не лише через відсутність спеціального обладнання, для тих хто його потребує, але й через брак досвіду та недостатньої кваліфікації спеціалістів. Здебільшого лише у спеціалізованих (реабілітаційних) закладах наявні відповідні фахівці, але їх кількість все одно недостатня для роботи 3 кожною окремою дитиною. Дієвим та ефективним у роботі 3 дітьми 3 інвалідністю може слугувати їх ранній розвиток, що можуть забезпечити дошкільні форми освіти. Тому визначення готовності дошкільних форм освіти до роботи 3 дітьми 3 інвалідністю $\epsilon$ нагальним завданням сьогодення у розв'язанні інклюзивних питань.
\end{abstract}

\section{Результати:}

Дошкільна освіта $є$ дуже важливим етапом розвитку дітей з інвалідністю, адже вона дає їм базу та поштовх до майбутніх досягнень, навчання та життя. Така освіта ще 3 ранніх років сприяє соціалізації дитини, тіі соціальній реабілітації та інтеграції в суспільство, навчає комунікативним вмінням, допомагає здобути початковий рівень знань про світ та науку. Важливим, при цьому, є іiі “включення" як в освітній процес, так і загалом в суспільні зміни.

Більшість закладів дошкільної освіти направлені на виховання, розвиток у дітей навичок комунікації, формує способи пізнання, розуміння самого себе та навколишнього світу, засвоєння дітьми способів розвитку та набуття нових знань, навичок та соціальних зв'язків, котрі згодом, в початковій школі, будуть укріплюватися та ставати більш стійкими до впливу ззовні.

Слід зазначити, що навчання дітей з інвалідністю безперервний процес, у якому мають брати участь не тільки фахівці дошкільних закладів, але й батьки, котрі проводять 3 дітьми достатньо часу $\mathrm{i}$ повинні підтримувати в них бажання до навчання та постійно його стимулювати.
}

Забезпечити ефективність діяльності дошкільних закладів освіти можуть кваліфіковані спеціалісти, що мають досвід у такій галузі. Для розв'язання проблем, пов'язаних 3 недостатньою кількістю фахівців, які компетентні у навчанні дітей 3 особливими потребами, необхідно провести ряд заходів спрямованих на покращення ситуації та надання дітям 3 інвалідністю дійсно якісної освіти та підтримки.

Найважливішими рекомендаціями щодо усунення, а для початку полегшення, такої серйозної проблеми, як неготовність дошкільних закладів освіти до роботи 3 дітьми, які мають інвалідність, можна забезпечити шляхом кількох напрямків роботи: перше - розгорнуте та поглиблене інформування вчителів дошкільних закладів про особливості дітей з інвалідністю, шляхи взаємодії 3 ними, проведення інформативних та пізнавальних семінарів та тренінгів профільної направленості; друге - відвідування курсів на обов'язковій основі, спрямованих на необхідні методи по роботі 3 такими дітьми; третє - соціально-орієнтовані програми, які працюють не лише в межах дошкільного закладу, але i за його межами; четверте - запровадження “літніх шкіл” для вчителів дошкільних закладів освіти, спрямованих на підвищення кваліфікації, обміну досвідом та семінари психологічного характеру й обмін знань із фахівцями соціальної роботи, використовуючи інтерактивні методи навчання, або ж здійснювати навчання 3 початкового рівня, для нових та недосвідчених спеціалістів. На таких таборах фахівці зможуть розробляти індивідуальну програму розвитку та навчання дітей 3 інвалідністю, враховуючи їх психологічні особливості та специфіку нозології дитини, iï соціальну ситуацію та направленість класу.

\section{Висновки: \\ Виконання вищезазначених рекомендацій може слугувати підвищенню готовності дошкільних закладів освіти здійснювати компетентну навчальну діяльність дітей 3 інвалідністю, котрі будуть якісно надавати їм не тільки знання, навички та розвивати таланти, але й підтримувати та давати поштовх на подальший розвиток та досягнення успіхів у майбутньому.}

\section{Інформація про автора:
Полівко Лариса Юріївна - кандидат} психологічних наук, асистент кафедри соціальної роботи, Київський національний університет імені Тараса Шевченка, Київ, Україна.

Наукові інтереси: соціальна робота, соціальна підтримка, соціально-психологічний супровід сімей, що опинилися в складних життєвих обставинах; http://orcid.org/0000-0002-9102-2779.

\section{Автор-Кореспондент:}

Полівко Лариса Юріївна

Email Автора-Кореспондента:

PolivkoLarisa@meta.ua 